Mеталлофиз. новейшие технол. / Metallofiz. Noveishie Tekhnol. (C) 2015 ИМФ (Институт металлофизики 2015, т. 37, № 4, сс. 555-558

Оттиски доступны непосредственно от издателя

им. Г. В. Курдюмова НАН Украины)

Фотокопирование разрешено только

Напечатано в Украине.

в соответствии с лицензией

PACS numbers: 61.05.cc, 61.05.cf, 61.05.cp, 61.72.Bb, 61.72.Qq

\title{
Static Krivoglaz-Debye-Waller Factor for Spherical New-Phase Particles
}

\section{O. S. Skakunova}

G. V. Kurdyumov Institute for Metal Physics, N.A.S. of Ukraine, 36 Academician Vernadsky Blvd., UA-03680 Kyiv, Ukraine

The explicit analytical expression for the static Krivoglaz-Debye-Waller factor is derived in the case of spherical amorphous clusters or new-phase particles. The simple approximate formulas are obtained in limiting cases of both small static distortions and large ones around the defects.

Виведено явний аналітичний вираз для статичного фактора КривоглазаДебая-Валлера у випадку сферичних аморфних кластерів або частинок нової фази. Одержано прості наближені формули в граничних випадках слабких і сильних статичних спотворень навколо цих дефектів.

Выведено явное аналитическое выражение для статического фактора Кривоглаза-Дебая-Валлера в случае сферических аморфных кластеров или частиц новой фазы. Получены простые приближенные формулы в предельных случаях слабых и сильных статических искажений вокруг этих дефектов.

Key words: X-ray diffraction, static Krivoglaz-Debye-Waller factor, amorphous clusters, new phase particles.

(Received March 11, 2015)

The non-destructive X-ray diffraction methods are widely used to determine characteristics of structural defects and strains in the asgrown and modified crystals, multilayer systems, etc. [1]. Efficiency of application of these methods is determined to large extent by the availability of the correct analytical expressions connecting basic diffraction parameters with defect characteristics. One of such most important parameters, used in both kinematical and dynamical X-ray diffraction theories [2,3], is the static Krivoglaz-Debye-Waller factor. 
The exponent of static Krivoglaz-Debye-Waller factor for randomly distributed defects is described by the following expression [2]:

$$
L_{\mathbf{H}}=c \sum_{t}\left[1-\cos \left(\mathbf{H} \mathbf{u}_{s t}\right)\right]\left(1+\frac{\varphi_{s t}}{f}\right) \approx \frac{c}{v_{\mathrm{c}}} \int d \mathbf{r}\{1-\cos [\mathbf{H u}(\mathbf{r})]\}\left[1+\frac{\varphi(\mathbf{r})}{f}\right],
$$

where $\mathbf{H}$ is the reciprocal lattice vector, $c$ is the defect concentration, $\mathbf{u}(\mathbf{r})$ is the static displacement of a crystal matrix atom due to a defect at distance $\mathbf{r}, \varphi(\mathbf{r})$ is a corresponding change of the matrix structure factor, $f$, and $v_{\mathrm{c}}$ is the unit cell volume.

For spherical amorphous clusters or new-phase particles with radius $R_{0}$, the field of static atom displacements in Eq. (1) can be written in the approximation of elastically isotropic continuum as follows [2]:

$$
\left\{\begin{array}{l}
\mathbf{u}(\mathbf{r})=\frac{A_{\mathrm{C}}}{R_{0}^{2}} \frac{\mathbf{r}}{r}, r \leq R_{0}, \\
\mathbf{u}(\mathbf{r})=A_{\mathrm{C}} \frac{\mathbf{r}}{r^{3}}, r>R_{0},
\end{array}\right.
$$

where the notations were used as follow:

$$
A_{\mathrm{C}}=\Gamma|\varepsilon| R_{0}^{3}, \quad \Gamma=\frac{1+v}{3(1-v)}, \quad \varepsilon \approx \frac{1}{3} \frac{\Delta v_{\mathrm{c}}}{v_{\mathrm{c}}},
$$

with $v$ being the Poisson ratio, and $\varepsilon$ is the strain at cluster interface. The corresponding change of the matrix structure factor for amorphous clusters or new phase particles with the structure different from that of matrix can be written as follows:

$$
\left\{\begin{array}{l}
\varphi(\mathbf{r})=-f, r \leq R_{0}, \\
\varphi(\mathbf{r})=0, r>R_{0} .
\end{array}\right.
$$

Then, one can derive from Eqs. (1) to (4) after performing the integration in spherical coordinates (cf. [2]):

$$
L_{\mathrm{H}}=3 c n_{0} \eta^{3} \int_{0}^{\eta} x^{-6}\left[x^{2}-\sin \left(x^{2}\right)\right] d x
$$

with notations used:

$$
\eta=\frac{\sqrt{H\left|A_{\mathrm{C}}\right|}}{R_{0}}=\sqrt{\Gamma|\varepsilon| H R_{0}}, \quad n_{0}=\frac{4 \pi R_{0}^{3}}{3 v_{\mathrm{c}}} .
$$

Parameter $\eta$ can be considered as a measure for the strength of static distortions around the defect. Indeed, according to Krivoglaz [2], the distortions are supposed to be small or large when corresponding 
conditions are fulfilled:

$$
\left|\mathbf{H u}\left(R_{0}\right)\right| \equiv \eta^{2}<<1 \text { or } \eta^{2}>>1,
$$

respectively.

The integral (5) can be taken easily by parts:

$$
\frac{L_{\mathrm{H}}}{3 c n_{0} \eta^{3}}=\frac{\eta^{2}\left[-5+2 \cos \left(\eta^{2}\right)\right]+\left[3-4 \eta^{4}\right] \sin \left(\eta^{2}\right)+8 \eta^{5} C(\eta)}{15 \eta^{5}},
$$

where $C(\eta) \equiv \int_{0}^{\eta} \cos \left(x^{2}\right) d x$ is Fresnel cosine. If distortions are small, i.e., at $\eta^{2}<<1$, we can put $C(\eta) \cong \eta$, and with precision up to terms quadratic in $\eta$ it follows from Eq. (8):

$$
\frac{L_{\mathrm{H}}}{c n_{0} \eta^{3}} \cong 0.525 \eta
$$

In an opposite case of large distortions, $\eta^{2}>>1$, the relation $C(\eta) \rightarrow 0.63$ holds, and it follows approximately from Eq. (8):

$$
\frac{L_{H}}{c n_{0} \eta^{3}} \cong 1
$$

Thus, for spherical amorphous clusters or new-phase particles with a structure different from the matrix structure, the following asymptotic expressions are valid:

$$
L_{\mathrm{H}} \cong\left\{\begin{array}{l}
0.525 c n_{0} \eta^{4}, \eta<<1, \\
c n_{0} \eta^{3}, \eta>>1 .
\end{array}\right.
$$

As far as the transition between asymptotic dependences (11) at strict calculations according to Eq. (8) occurs in the narrow range $1<\eta<3$ (see Fig. 1), the simplified formula with continuous dependence of $L_{\mathbf{H}}$ on $\eta$ can be used for practical purposes:

$$
L_{\mathbf{H}} \cong\left\{\begin{array}{l}
0.525 c n_{0} \eta^{4}, \eta \leq 1.9, \\
c n_{0} \eta^{3}, \eta>1.9 .
\end{array}\right.
$$

It should be remarked that, in the argument range pointed above, the deviation of approximated formula (12) from the calculation using exact formula (8) does not exceed $15 \%$, whereas outside this range it is smaller than $4 \%$.

The additional contribution to the value of $L_{\mathrm{H}}$ calculated above arises in the case when the structure of a new phase particle coincides with 


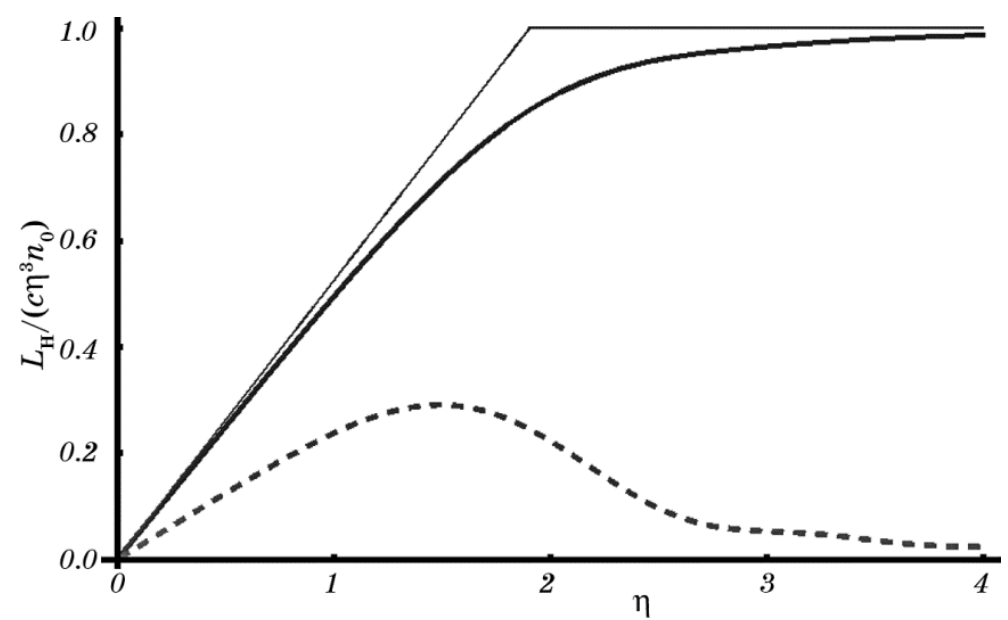

Fig. 1. Exact and approximated dependencies of the normalized exponent of static Krivoglaz-Debye-Waller factor $L_{\mathrm{H}} /\left(c \eta^{3} n_{0}\right)$ on $\eta$ (thick and thin solid lines, respectively). The contribution from coherent new phase particles at $\Delta f / f=0.5$ is shown by dashed line.

that of the matrix and differs only by a value of structure factor, i.e. by $\Delta f$. Then, the integration in Eq. (1) with account for the change in Eq. (4), i.e. $\varphi(\mathbf{r})=\Delta f$ at $r \leq R_{0}$, gives the additional term in formulas (8) and (12):

$$
\Delta L_{\mathrm{H}}=c n_{0}\left[1-\eta^{-2} \sin \left(\eta^{2}\right)\right]\left(1+\frac{\Delta f}{f}\right) .
$$

The behaviour of this contribution at the constant value $\Delta f / f=0.5$ is shown in Fig. 1 separately by a dashed line and, as can be seen, is important only at small values of $\eta \leq 3$.

\section{REFERENCES}

1. Diffuse Scattering and the Fundamental Properties of Materials

(Eds. R. I. Barabash, G. E. Ice, and P. E. A. Turchi) (New Jersey: Momentum Press: 2009).

2. M. A. Krivoglaz, X-Ray and Neutron Scattering in Nonideal Crystals (Berlin: Springer: 1996).

3. V. B. Molodkin, S. I. Olikhovskii, E. N. Kislovskii, T. P. Vladimirova, E. S. Skakunova, R. F. Seredenko, and B. V. Sheludchenko, Phys. Rev. B, 78: 224109 (2008). 